10.2478/v10103-011-0021-3

\title{
Conditions of the Development of Logistic Centers in Poland in the Context of European States` Experiences
}

\begin{abstract}
Development and exploitation of logistic centers in Poland depends on many conditions. The most important ones are: localization, structuralorganizational, economical and legal conditions.

The author makes a synthetic analysis of these conditions in the context of experiences of Western Europe states in this field. He gives the examples of solutions that function in high-profile countries, such as: Germany, Italy, Holland, Austria, France, England. The author pays attention to an important problem of the state`s engagement in development of logistic centers in Poland.

The article is, for the most part, the aftermath of his own examinations carried out in years 2007-2010 and concerning logistic centers development conditioning.
\end{abstract}

\section{Introduction}

The basic problems with formation and development of logistic centers in Poland are still in an open phase of solution-considering the situation in countries of Western Europe. Taking under consideration the fact that investors in Poland are going to make investment decisions concerning the construction of

\footnotetext{
${ }^{*}$ Ph. D., University of Łódź
} 
logistic centers -it is essential to describe macroeconomic conditions of construction and exploitation of logistic centers.

It is necessary to consider these conditions from the point of view of security of interests of main decision makers of the construction of the logistic center, it means authorities representing interests of local communities, investors and buyers of logistic services. They are of multiple character.

European logistic centers have been shaped for many years. At the beginning the sources of initiative of the construction of logistic centers were different and undertaken actions did not prejudge the fact whether a logistic center or another object would be built. They were concentrated on solving local problems of economical development or realization of plans of shaping of the space order by concentration economical activity in portioned out areas of the city agglomeration. As a result of this long-distance politics of local authorities and the state administration, often, after many years since first decisions, conditions for the construction of logistic centers appeared (Fechner 2005).

Centers of logistic services in Western Europe-as earlier planned investments-were built in the 80-ties and the 90-ties of the XXth century. However earlier we could observe the formation of districts, bases and storehouse zones. The Creation of logistic centers was caused by the fact, that construction of such objects made possible the influence on harmonious economical development of regions and mitigation of transportation problems resulting from domination of the car in goods transportation. The construction of logistic objects was supported by governments of European countries and their involvement became a form of programmes supporting development of such objects. The pioneers and leaders in the field of organization of this type of logistic ventures are: Germany, Italy, France, Great Britain.

In the context of long years of experiences worked out by these countriesthe question concerning conditions and choice of proper model of development of logistic centers in Poland -is up-to-date.

\section{Features of development of logistic centers in Western Europe}

\subsection{The German experience}

Because Poland and Germany are neighbours and EU members, but mostly because of author' over two-decade long experience of planning, 
establishing and operating logistics centres in Germany, the German organizational, legal and technical solutions will be presented more in detail.

In Germany, likewise in other western European countries, logistic centres started to emerge much earlier than in Poland. German authorities realised the macroeconomic benefits of establishing logistics service centres already in the 1970s. It was found then that an extending network of logistics facilities providing services such as cargo reloading, warehousing and handling could effectively ease the transport burden in the regions, particularly in the centres of urban agglomerations.

In Germany, logistics centres were established as a result of close cooperation between the public sector and private investors, even though the latter were aware of high risks the process involved. Private shareholders were more inclined to modernise and bring to life the old storage facilities. Under these circumstances, the public sector chose to pay all construction costs of logistics centres, thus releasing private investors from having to commit significant funds and minimising their investment risk. An important determinant of cooperation being started, or not, was the reach of the future logistics centre, i.e. whether a given facility would provide local or international services.

A systemic expansion of logistics centres started in Germany in 1992. The first facilities were built under the First Main Plan, which provided for the construction of 44 logistics centres with infrastructure for handling combined transport. The Second Main Plan drawn up in 1995 anticipated the construction of 39 logistics centres.

The German way of starting logistics centres is characterised by strong support from all-level public bodies, which has its source in the federal and Länder laws. Investment projects involving logistics facilities are assisted by the Länder authorities and local governments that use various financing models to grant aid. This makes the German public sector a special factor in both planning and construction of logistics centres.

\subsection{The Italian experience}

In Italy, first logistics centres appeared as early as the 1970s. The projects were usually carried out on an individual basis and their success frequently depended on the involvement of the public sector that in many cases initiated and joined particular investments. The sector's active role included stimulation of particular regional economies, establishment of consortia initiating the 
construction of logistics service centres and acquisition of shares in companies to carry the projects out. The involvement of the Italian government led to the development of the Main Transportation Plan that contained planning decisions regulating the development of railroad transport and logistics centres.

Because the logistics centre construction programme in Italy emphasised international cooperation, the centres were located in the more industrialised regions of northern Italy.

The financial support that the Italian government targeted to investors projecting to build or modernise logistics facilities, combined transport operators and Italian railways was regulated by the law in force and the programme's criteria. The budget instruments used to this end encompassed subventions and low-interest loans, as well as credit guarantees and credit facilities. In some cases, low-interest or zero-interest loans financing the purchase of specialist equipment for the logistics centres, combined transport wagons and intermodal transportation units were also available. The Italians chose to modernise many combined transport routes and to enlarge the number of logistics terminals predicting that the number of combined transport trains would double in their country. The same belief encouraged the Italian government to extend the national logistics network.

The Italian logistics centres did not have problems finding willing business occupants. The asymmetric economic development in the country caused that the planners directed most new investments to logistics centres in south Italy, where the economy and enterprises' industrial activities are much less vigorous than in the north.

\subsection{The experiences of other European countries}

The other European countries also use a whole range of instruments to support the creation of logistics centres.

In the Netherlands, financial support mainly having the form of subventions, low-interest loans, credit guarantees and credit facilities is offered by the national budget and to some extent by the regional and local budgets. In addition to the construction of logistics facilities, the aid can be used:

- to modernize railway lines and to provide the stations with cargo handling equipment,

- to improve inland waterways,

- to pay a portion of purchase costs of intermodal transport units, 
- to cover some combined transport operating costs (this use is mainly limited to the opening of new routes).

The financial support given by the state budget is supplemented by the regional and local budgets. The qualifying beneficiaries are operators of public terminals, inland navigation companies, combined transport operators, forwarding agents, road carriers and logistics firms.

Austria is another country where the public sector contributes financially to the expansion of the logistics centre network. The range of instruments available for boosting and promoting the development of intermodal transport includes grants to investments in logistics terminals and to purchases of loading equipment, special equipment and rolling stock, as well as subsidies for railway operating costs. Additionally, the Austrian government offers reliefs and exemptions for taxes and road user charges. These types of financial aid are directly linked to the creation and operation of logistics centres. Before it is granted, each type is examined vis-à-vis the pertinent laws and the applicable legal basis depends on the type of fund that will be used to finance a given investment.

In Austria, as in the Netherlands, all logistics projects are eligible for financial support from the government, private investors and local and regional budgets. In the latter case, though, only logistic facilities that clearly promise to significantly further regional development qualify for assistance.

France also offers financial support to projects extending the domestic logistics network. Most funds are allocated under the government combined transport development programme being an integral part of „The General Transport Development Programme in France" to activities stimulating the development of intermodal transport. One the goals the French aspire to achieve is an increased number of railway connections. A case in point is the new double-track ,express railway” constructed between France and Italy

Another way of promoting combined transport is supporting the construction, modernization and fitting out of terminals. Although most of the aid funds, such as grants, low-interest loans, credit guarantees and credit facilities come from the national budget, the local budgets are also involved. Investments in terminals are eligible for subsidies reaching up to $50 \%$ of their costs (the national and local budgets provide $70 \%$ of the funding and the French railways contribute the remaining 30\% from). In France, mainly combined transport operators, railways, terminal operators and road carriers qualify for support .

As far as the major logistics centres in Europe are concerned, the maritime logistics centres in Finland and the logistics facilities in the UK and Spain are worth noting. The Finnish centres are representative of how the 
locational potential of seacoast and seaports can be utilised for this type of facilities.

An example of the UK logistics centres is the United Distribution Centre being part of the domestic network of distribution centres. It is located in Western England, in the vicinity of two motorways. The Centre has warehouse space of $10,780 \mathrm{~m}^{2}$ and ships goods to retailers in West and West Central England and South Wales (Beier, Rutkowski 2006 p. 106).

Another facility that belongs to the largest and best thriving logistics centres is the Spanish Mataro Distribution Centre (warehouse space of 41,800 $\mathrm{m}^{2}$ ). It was established in 1993, after a motorway was constructed between Barcelona and Madrid.

Western Europe boasts around 120 logistics centres today, half of which are members of the research project "bestLog" that coordinates their cooperation in 7 countries (Denmark, France, Germany, Spain, Luxemburg, Portugal and Italy).

Development of logistic centers in Western Europe became an important factor of their economical development. Thanks to them the organization of distribution of goods became better, also the traffic capacity of transportation corridors was enlarged.

At present most European countries support the initiative of the construction of logistic centers .Mainly the need of their network cooperation is underlined in global economy. In European countries different projects appear, which have the purpose to support creating logistic centers. Consciousness of the public sector is an important element, which by different forms of activity supports and makes the process of creation of logistic centers dynamic.

In most countries in Western Europe we observe forms of close cooperation of the public sector with private investors. For example in Germany the public sector covers totally or partly all costs of the construction of logistic centers.

Even in the situation, when the investment initiative is of individual character (for example-Italian economy) involvement of the public sector decides about the success in creation of centers. The public sector gives financial support to potential investors of logistic objects. Forms of financial help are low-percentage subvention of loans, credits or credit guarantees.

Next to strong support of governments of European countries, we can observe a phenomenon of common organization in logistic undertakings of local and regional governments, regions' and cities' administrations and even commercial chambers. Very often these investments are supported by fast 
legislative activities, voting legal resolutions supporting development of logistic centers and intermodal transportation (Kaźmierski 2009, p. 165).

Another important development feature of logistic centers in western and southern neighbouring countries is taking under consideration the concept of localization of logistic centers on the country territory. While choosing a place, coordination with development plans of different transportation branches-especially inland and intermodal-take place and also earlier made analysis of the potential market of receivers of logistic services.

- It is also necessary to consider the environment protection aspect. Localization of logistic centers near cities and agglomerations can not be contradictory with ecology, which is a very important element taken under consideration while designing logistic centers.

- Multiple instruments - especially financial help-are in Europe the factor, which directly corresponds with competition among regions. Regions, where authorities show activating, initiating support get a competitive advantage and can make further development dynamic.

- Development of logistic centers can play a double role. They can help in achieving growing requirements considering environment quality and also help in better competition of enterprises services receivers, and the competition of regions, where they function. As a consequence it will lead to economical growth and competition of economies of EU countries. This tendency is compatible with the Lisbon Strategy realization, creating a chance for development of logistic centers as an important instrument in well-balanced development.

\section{Localization conditions}

One of the most important factors concerning development of logistic centers is their localization, especially - criteria of the choice of localization of centers. If we assume that development of logistic centers should include the public sector participation, we should describe, what localization conditions should be taken under consideration.

Generally saying, the main criterion is the market-to be specific-so called values of demand ( which means the needs of companies for logistic services). The access to a territory and transportation and communication infrastructure, values of resources(of space and infrastructure essential for the center development) is a factor limiting and giving the direction for the possibility of development of centers (Beier, Rutkowski 2006, p. 108). Configuration of 
development of logistic centers the country depends on following, general conditions (Kaźmierski 2009, p. 311):

- Spatial arrangement of modal network points, it means such ones, where loads displace with the lowest costs. This arrangement depends on a suitable transportation infrastructure(wheel roads, railway stations, water roads, airports, reloading terminals), which has an influence on costs of goods transit. The arrangement of transportation network should be the basis for making up a map of goods` flow, providing information for localization of logistic centers,

- Logistic absorbency of the region or another territorial unit,

- Costs of the access to the market and to the area of the construction of the center.

Taking under consideration the points above, geographical situation, localization on the junction of important communication roads, existence of special economic zones, the access to well-educated staff, developed metropolitan functions, low prices of the land, précised strategy of city/local development or existence of logistic cluster are examples of trump cards of territorial units creating proper conditions for development of logistic centers. The basic condition of localization of logistic centers is connection of a few kinds of transportation (Burnewicz 2006).

Localization of big, logistic centers of regional or trans-regional character would require an analysis of external and internal conditions in appropriate scale. Because of trans-local character of such undertakings it should be an analysis conducted at least in a regional scale. At the same time it should include guide lines marked out in a space design on the country level. Such an attitude would assure optimum disposal in the country space of big logistic centers connected with the superior communication arrangement.

\section{The Structure and organization conditions. The choice of model of a logistic center}

Structural and organizational solutions of a logistic center should be dependent on accepted general model of initiating its construction, it means on evolutionary or embryo model (Kaźmierski 2009, pp. 313-314).

The first of them is a natural way of formation of the concept of a logistic center based on long-term politics of economical development of the region, heading for economical activity and the same time building the demand for logistic services and supply of these services (logistic operators acting in this 
region). As a result conditions for the construction of a logistic center appear. This model involves the smallest risk, because the decision on going ahead with the construction of a logistics centre is only taken after the current demand for logistics services and potential project participants has been identified.

The second center is going to satisfy existing demand based on functioning of suppliers of logistic services on the market. That model presumes economic activation of a chosen area by creating suitable conditions encouragements and facilities for investors. As a result on such area, concentration of independent economical subjects appears and the next step of development is to build the logistic infrastructure (for example: railway container terminal, storehouses, goods yard etc.) creating this way a logistic center. The elements that future occupants find attractive are integrated logistics infrastructure consisting of a railway container terminal, warehouses and stacking yards, as well as plots of land readily available for investors' own projects and having good access to the network of railroads, which makes them a desired asset.

There is also a third, virtual model, where the logistics centre integrates the scattered facilities and logistics infrastructure by means of information linkages, thus forming an electronic market for logistics services.

Polish experiences, which we have received so far, are connected with cases of construction of logistic centers by private investors, which appeared around big agglomerations, induce(tend) to formulate a preferred attitude towards the structure and organization formula of construction of concentrated logistic centers (where there are all objects in one excreted organizationalfunctional space.

Dynamic development of the storehouse surface built by developers for a rent and by other economical subjects for their own needs, creates conditions for a concept of impersonal logistic center as an alternative for concentrated logistic center (Fechner 2006).

The concept of an impersonal logistic center predicts connection of resources belonging to different economical subjects by IT platform providing facilities for building the packet of services and their consolidation in the form of offers for customers. We think that this model is fundamental in the situation, when the initiator of the construction of a logistic center has limited number of investment areas. In this case "a virtual-associated" connection with impersonal logistic objects and their owners, located on the area of the activity of a logistic center could help in a complex logistic service for clients (Kaźmierski 2009, p.314).

The model of concentrated logistic centers should take under consideration the situation on the market surroundings, which existing market of 
logistic services with the logistic infrastructure is an element of. It is essential to plan such investments, which would take under consideration existing potential of logistic services together with the possibility to include this potential partly in the activity of a logistic center.

\section{Economical and market conditions connected with the development of logistic centers}

The question about advantages and costs of functioning of logistic centers is a question about effectiveness of such a center-in the whole country scale. We can judge it using different instruments, their choice has a fundamental meaning, if we want to answer the question about advantages and costs of centers activity (Rodawski 2006, pp. 88-89). If we analyze financial activity of the logistic center, the measurement of effectiveness is made from the point of view of direct participants-subjects involved in a given undertaking (logistic center). Wider insight in this problem, economical analysis gives to us, where we take under consideration also the influence of a given investment or a project on surrounding reality.

Economical analysis should reflect social costs of this undertaking. It is important, because the analysis of effectiveness of functioning of logistic centers is not coordinated from the point of view of effectiveness of the whole economy. It happens when linear elements of a technical infrastructure (roads) are built in a planned way, but point elements appear spontaneously(centers), which not necessarily makes the logistic center optimum from the point of view of the whole economy.

The analysis of costs and advantages made for evaluation of investment projects in logistics, should be made from three points of view: investors, closer surrounding(like-local communities) and the whole economy. It would require involvement of positive and negative external effects of logistic activities in an arrangement-investor-region(community)-economy, which makes out of market effects of functioning of logistic centers and so called external effects (Markowski 2007, pp.35-36). These activities create a full economical analysis and they are quite complicated. However they are essential in the situation when the public sector intervene in the process of centers` creation.

Taking under consideration market conditions connected with 1 functioning of logistic centers we think that big demand for this center services adequate to planned size and organization structure of this investment, is the key factor of their effective functioning (Kaźmierski 2009). Because of this fact estimation of current and future demand for logistic center services and factors 
determining its size, is an important problem in the analysis of the exploitation construction profits.

Demand for logistic services creates conditions, storehouses and transshipping stations, connected with describing factors, which influence inclination of enterprises for allocation its activity partly in the region.

\section{Legal conditions connected with gaining areas and the construction of logistic centers}

One of the basic conditions of the construction of a logistic center is free from legal ballasts big investment areas intended for economical activity according to the local plans of making the space productive. These plans are made from the point of view not only of supplying the demand for logistic services, but also these plans take under consideration different social needs, such as: generation of new workplaces, stimulation of economical growth, making some areas redundant (postindustrial) - more productive, etc.

Taking over areas, which were intended to be used for the construction of a logistic center, can run by applying for apport into undertaking by local authorities, which is the most attractive way to acquire rights for this area by the logistic center. The method of purchasing areas is expensive, the more investors meet speculative behavior on the real estate market. In practice it forces them to purchase the whole planned area at the beginning of the undertaking.

When investors purchase areas very often they must integrate it, which generates additional expenditures. From the point of view of these expenditures long-term leasing agreement can be an attractive form of acquiring rights for this area, mostly from public owners, who expect incomes in a long time period.

Also there are problems of legal nature, such as long procedures, the possibility of protests and changes in spatial plans. The situation can be also complicated, when some areas have not regulated the lawful ownership.

Because of these reasons some areas are excluded from possibility of becoming a logistic center. It seems that there is a realistic need for new regulations on the central level (government, parliament).

In recent years in Poland advantageous changes have taken place in terms of the construction of logistic centers, mainly because of financial help from EU and the bill of public-private partnership (PPP), which has got some mistakes and is often criticized, can make easier cooperation between public and private sectors. It is known that the bill PPP and: "THE law for the public order" create conditions for realization of undertaking of the construction of logistic centers. 


\section{The need for public authorities to become involved in logistics centre development}

What speaks in favour of public authorities' involvement in the development of logistic centres is the need to regulate inefficient real property markets, whose functioning is strongly affected by metropolization processes today. Inefficient markets reduce the locational competitiveness of some regions as the likely hosts of logistics centres.

This is why logistics centre development in Poland should become an item addressed not only by the central and local government programmes and initiatives such as the National Development Plan, the National Strategy of Regional Development, the Concept of Spatial Development of the Country, the State Transport Policy, but also by development strategies drawn up at the subnational and lower levels of territorial self-government.

A discussion concerning the logistics centre development policy and its instruments should not omit the operational factors that the governments wishing to stimulate the centres' growth (Kaźmierski 2009, pp. 322) need to deal with. These are:

- inter-regional competition and territorial marketing - a sort of "a market place" where local governments compete for large investors,

- domestic capital - too weak today to shoulder the high construction costs of the centres,

- foreign capital - expecting a system of incentives to be available before projects are launched, such as access to the appropriate infrastructure.

Because of these factors, logistic centre development is a process requiring active participation from the public sector, as well as being a phenomenon that must be forecasted and coordinated according to the country's economic interests, rather than being only watched, as it has been so far.

This conclusion is imposed by the present lack of public logistics centre development policy and the minimal support the centres receive from the public sector. The unavailability of laws regulating this activity translates into high external costs, mostly arising from inappropriate and frequently accidental location of the facilities (non-optimal from the standpoint of national economic interests). The passive stance of public authorities, involving non-action and indecisiveness, does not make the decision-makers less accountable.

A serious problem is the shortage of publicly funded studies on the location of logistics centres and of investigations into public policy instruments and effects on the emergence of large-scale projects. 
Broadly speaking, the Polish system of spatial planning instruments is very limited, accompanied by low-quality executive regulations and inefficient enforcement thereof, which impedes public coordination or management of logistics centre development. A discussion on the public sector's involvement in this process should define the central government and local governments' roles and priorities. Regarding the latter type of authorities, the areas of involvement appropriate for units representing different tiers of administration should be established.

It is advisable that state administration give the status of public purpose projects to centres rated crucial for the national economy, as well as incorporating them into the Concept of Spatial Development of the Country. Another major goal should be the provision of some formal framework to foster the development of public-private partnerships. Owing to this, local governments could become public partners to private investors considering logistics projects.

In the latter case, the large cities (municipalities) being economically much stronger than private investors would make more appropriate partners, because their potentials would allow them avoid the domination of large private investors. While the local governments should focus on providing investors with the necessary infrastructure, the regional authorities should rather coordinate spatial planning activities in the communes (regulate their competition for locating facilities in the metropolitan areas, for instance).

The regional authorities should contemplate the use of funds available under integrated regional development operational programmes as a means supporting the growth of logistics centres.

\section{Public authorities' instruments for controlling logistics centre development}

Generally, public authorities pondering over the choice of instruments that could encourage investors to establish and expand logistics centres should use the market solutions in the first place. The main principle to guide regional and local governments' interventions should be that action is only taken where the market seems to be inefficient and that whatever is undertaken must respect the fundamentals of the market concept.

It is possible to stimulate the growth of logistics centres by creating the following instruments (Kaźmierski 2009, pp. 323, 324): 
1. regulations particularly addressing this process, with indication of the available funding sources,

2. a government logistics centre construction / development programme, with the ensuing projects being given the status of public purpose investments; the programme should be provided with concrete financial instruments,

3. encouraging public-private partnerships to undertake investment projects,

4. regional spatial planning - coordination of communes' competition for logistics projects,

5. simplification of the procedures applying to investment location,

6. tax exemptions and/or tax rate reductions.

Before the logistics centre development policy can be made operable, the impacts of its instruments, such as the provision of infrastructure, tax reliefs, etc., should be considered. Communes' competition for logistics centres must be regulated too, because local projects must be a vehicle for expressing the paramount national interests. All this clearly proves that the government must have a logistics centre policy.

The current policy concerning large-scale investments (see National Cohesion Strategy) emphasises the decentralised distribution of public aid funds. The logistics centre development policy should match the Concept of Spatial Development of the Country. The future government policy will have to tackle the following key question: should public authorities influence the establishment of logistics centres and, if the answer is yes, what mode of intervention is appropriate. To answer the question, the opportunity costs must be considered, i.e. the costs of political decisions (of government interventions) must be weighed against social costs.

As mentioned, a logistics centre construction programme treating such facilities as public purpose investments could be funded (or co-funded) by the national budget. It is quite probable that the World Bank's funds would also contribute, if a relevant development programme were put together. When public aid is taken into account as a way of stimulating the emergence and growth of logistics centres (let us remember that public budgets are tight), it is crucial to remember that returns to scale (benefits from centres established to serve the entire national economy) can be obtained if public funds are carefully addressed to selected facilities of special importance for the country's economy, rather than indiscriminately. This approach helps prevent the dispersion of public funds, while making them as effective as possible.

The decisions on whether, where (the region) and when a logistics centre should be located must be based on an informed action plan preceded by an analysis of the condition and potential of particular regional economies. 
Given the above, logistics centre development in Poland should be seen as an important field for public interventions aimed at boosting their growth. Two types of interventions having entirely different nature, but not totally unrelated, are possible.

The first type deals with the economic aspects that require concentration on the solutions stimulating the market (taxes) and the use of real estate, and on public-private partnership mechanisms.

The other type concerns spatial management and protection of the natural and cultural environments; a direct intervention (emphasising logistics centres as public purpose tasks) may prove to be the only effective tool here. This means that the intervention tools indicated above must enhanced with additional solutions.

The division of interventions into the two categories seems rational, as this approach allows choosing public intervention tools and methods that more suitable for particular situations.

\section{Conclusion}

Development solutions in construction and exploitation of logistic centers coming from Germany or Italy, presented in the point number 1 of this article, can be a valuable source of experiences for Poland.

In our country any model of realization of public politics towards logistic centers has not occurred yet. Initiators of their construction work individually and their negotiations with local governments are considered as difficult. It can cause an astonishment, because Poland as a transit country, is regarded as one of more attractive areas for this type of logistic investments.

The elementary argument saying that, there is a need for the state engagement in development of logistic centers and the need for regulations in the deformed real estate markets, is under strong process of metropolization of the space.

We can set up the thesis that today Poland is still at "the stage of localization" of logistic centers, however taking under consideration experiences of other European countries, this process cannot be negligent. In this context the problem of development of logistic centers should be considered as an important field of public intervention. 


\section{References}

Beier F., Rutkowski K. (2006), Logistics, Publisher SGH, Warsaw

Bretzman K.H., Wenske Ch. (2005), Planning of logistics centers. Final Report, Gdańsk 2003, [in:] Meidute I., Comperative analysis of the definitions of logistic centers, 'TRANSPORT', Vol. XX, No 3

Burnewicz J. (2006), Logistic centers- the lacking element of Polish transportation system, 'Communicative Review', Association of Engineers and Technicians of Communication R.P., Warsaw no. 7-8

Cookie P., Schienstock G. (2002), Structural Competitiveness and Learning Regions, 'Enterprise and Innovation Management Studies', Vol. 1, No 3

Fechner I. (2004), Models of logistic centers 'initiating (part I), 'Logistics', Institute of Logistics and Stockpiling, Poznan, no. 4

Gołembska E. (2004), International logistics in theory and practice, Publishing House of Economical Academy, Poznan

Kaźmierski J. (2009), Logitics and the regional development, Publishing House of Lodz University, Lodz

Kaźmierski J. (2009), Macroeconomic conditions of construction and exploitation of logistic centers, [in:] Maciej Urbaniak - The role of management sciences in the economy founded in knowledge, Publishing House of Lodz University, Lodz

Kaźmierski J. (2010), Rola państwa w rozwoju centrów logistycznych, 'Eurologistics', nr 4/2010

Logistics Centers Directions for Us. (2004), Europlatform EEIG,

http://www.unece.org./trans/main/eatl/docs/EN-REV

Markowski T. (1994), The meaning of external effects in the city development-theory and reality, [in:]Jerzy Rogulski (editor) - The city and its authorities, Ossolineum, Wroclaw

Markowski T. (2007), Management of cities` development, Publishing House of Economical Academy, Warsaw

Rimiene K., Grundey D. (2007), Logistic centre concept through evolution and definition, 'Engineering Economics', No 4 (54), Commerce of Engineering Decisions

Rodawski B. (2006), Evaluation of effectiveness of a logistic center, [in:] Tadeusz Markowski (ed.) - The role of logistic centers in the economical and spatial development of the country, Polish Academy of Sciences, KPZK, Warsaw 


\section{Streszczenie}

\section{UWARUNKOWANIA ROZWOJU CENTRÓW LOGISTYCZNYCH W POLSCE W KONTEKŚCIE DOŚWIADCZEŃ PAŃSTW EUROPEJSKICH}

Rozwój i eksploatacja centrów logistycznych w Polsce uzależnione jest od szeregu uwarunkowań. Najistotniejsze $z$ nich to uwarunkowania: lokalizacyjne, strukturalno-organizacyjne, ekonomiczne oraz prawne.

Autor dokonuje syntetycznej analizy tych uwarunkowań $w$ kontekście doświadczeń krajów Europy zachodniej w tym zakresie. Daje przykłady rozwiazań, jakie funkcjonuja $w$ czołowych krajach, takich jak: Niemcy, Włochy, Holandia, Austria, Francja, Anglia. Omawia również ważny problem, jakim jest angażowanie się władz publicznych $w$ rozwój centrów logistycznych $w$ Polsce oraz instrumenty, jakie moga być wykorzystywane we wspieraniu ich rozwoju.

Artykut jest $w$ znacznej mierze pokłosiem badań własnych autora przeprowadzonych w latach: 2007-2010 dotyczqcych uwarunkowań rozwoju centrów logistycznych. 